\title{
Performance, blood indices and carcass yield of grower rabbits fed diet containing Moringa oleifera, Aspilia africana and Azadirachta indica leaf meals

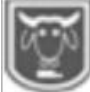 \\ Abstract \\ Bolarin', O., Oni ${ }^{1}$, A. O., Olanite ${ }^{2}$, J. A., Onwuka ${ }^{1}$, C. F. I ${ }^{1}$ \\ ${ }^{I}$ Department of Animal Nutrition, \\ ${ }^{2}$ Department of Pasture and Range Management, Federal University of Agriculture Abeokuta E-mail: bolarinoluwabunmi@yahoo.com
}

The experiment was conducted to examine the effect of feeding varying dietary levels of Moringa oleifera meal (MOM), Aspilia africana meal (AAM) and Azadirachta indica meal (AIM) on performance, blood indices and carcass yield of grower rabbits. Eight one rabbits were grouped into 9 treatment, each treatment were replicated thrice, containing 3 rabbits per replicate. Diets containing MOM, AAM and AIM at 0, 15 and $30 \%$ respectively were formulated. Rabbits fed inclusion levels of 15\%, 30\% MOM and 15\% AAM (4.92 g, $4.90 \mathrm{~g}$ and $4.95 \mathrm{~g}$ respectively) had the best feed conversion ratio. However, the inclusion of $30 \% \mathrm{MOM}$ in the diet increased the weight gain and better protein intake. The nitrogen intake, nitrogen absorbed and retention followed the same trend. Inclusion levels of the leaves had no negative effect on the blood indices of rabbit fed the dietary treatments. Rabbits on 30\% MOM had significantly $(p<0.05)$ higher slaughtered weight $(1,224.3 \mathrm{~g})$, carcass weight $(902.64 \mathrm{~g})$, dressing percentage (61.58\%), loin (194.20 g) and shoulder (193.05 g) weights. It was concluded that inclusion of $30 \%$ MOM in the diet of grower rabbit had the best performance.

Keywords: Moringa oleifera, Aspilia Africana, Azadirachta indica and rabbits

\section{Introduction}

Most of the meats currently consumed in Nigeria, especially in the urban and periurban region, come from ruminant species, pigs and poultry, especially chickens which supply an Nigerian with $7.9 \mathrm{~g}$ of animal protein intake per day which is far below the recommended level of $35 \mathrm{~g}$ per day required by an average adult for proper health (FAOSTAT, 2011). The situation may become worse in the future unless there is drastic re-orientation aimed at increasing output in the livestock subsector.

Efforts have only focused on the major traditional livestock species including ruminants, pigs and chickens, with little attention paid to rabbit. One of the ways of bridging the demand supply gap of animal protein is through rearing of rabbits. What inspired the interest in rabbit are its short generation interval, high prolific, ability to thrive on forages that cannot be consumed by man, efficient converter of feed to meat and utilizes up to $30 \%$ crude fibre as against $10 \%$ by most poultry species. Rabbit is increasingly becoming an important meat source worldwide and is now recommended for production in countries that are experiencing animal protein shortage (Ewuola etal., 2012).

Rabbit have the potential of utilizing some tropical legumes and browse plants notably moringa (Moringa oleifera) (Ewuola et al., 2012), Mucuna utilis leaf meal (Sese et al., 2013), neem leaf (Azadirachta indica) (Ogbuewu et al., 2010), Bush marigold (Aspilia africana). Leaf meals of these plants have attracted attention for their ability to provide large quantity of high quality forages all year round and readily come to mind as a protein source with lots of potentials to be exploited in rabbit feeding. Haematological components of blood are 
valuable in monitoring protein quality of feeds (Atansuyi et al., 2012), feed toxicity especially with feed constituents that affect the formation of blood (Oyawoye and Ogunkunle, 1998). The serum chemistry and haematological blood components are influenced by the quality and quantity of feed and the level of anti-nutritional element or factors present in the feed (Akinmutimi, 2004). This study examines the effect of the leaf meals of M. oleifera, $A$. africana and $A$. indica on the performance, blood indices carcass yield of grower rabbits.

\section{Materials and methods Experimental site}

The experiment was carried out at the Rabbitary Unit of Directorate of University Farms (DUFARMS), Federal University of Agriculture, Abeokuta, Ogun State, Nigeria.

\section{Experimental animals and management}

Eighty one, New Zealand white and red weaner rabbits of both sexes between ages 5-6 weeks old with initial body weight of 516.42-516.67 g were used for the experiment. The rabbits were kept individually in a wooden hutch with a wire mesh floor. The condition of the housing and management were the same for all the experimental animals for a period of 12 weeks.

\section{Experimental procedure}

The rabbits were randomly allotted on weight equalization basis into 9 dietary treatments with 9 rabbits per treatment.

Treatment $1\left(\mathrm{~T}_{1}\right)-0 \%$ concentrate only;

Treatment $2\left(\mathrm{~T}_{2}\right)-15 \%$ Moringa oleifera

Treatment $3\left(\mathrm{~T}_{3}\right)-30 \%$ Moringa oleifera;

Treatment $4\left(\mathrm{~T}_{4}\right)-0 \%$ concentrate only;

Treatment $5\left(\mathrm{~T}_{5}\right)-15 \%$ Azadirachta indica;

Treatment $6\left(\mathrm{~T}_{6}\right)-30 \%$ Azadirachta indica;

Treatment $7\left(\mathrm{~T}_{7}\right)-0 \%$ concentrate only;

Treatment $8\left(\mathrm{~T}_{8}\right)-15 \%$ Aspilia africana

Treatment $9\left(\mathrm{~T}_{9}\right)-30 \%$ Aspilia africana

Table 1: Composition of the experimental Diet

\begin{tabular}{|c|c|c|c|c|c|c|c|c|c|}
\hline \multirow[b]{2}{*}{ Ingredients } & \multicolumn{3}{|c|}{ Moringa oleifera } & \multicolumn{3}{|c|}{ Azadirachta indica } & \multicolumn{2}{|c|}{ Aspilia africana } & \multirow[b]{2}{*}{$\begin{array}{l}\mathbf{T}_{\mathbf{9}} \\
\mathbf{3 0 \%}\end{array}$} \\
\hline & $\begin{array}{l}\mathbf{T}_{1} \\
\mathbf{0 \%}\end{array}$ & $\begin{array}{c}\mathbf{T}_{2} \\
\mathbf{1 5 \%}\end{array}$ & $\begin{array}{l}\mathbf{T}_{3} \\
\mathbf{3 0 \%}\end{array}$ & $\begin{array}{l}\mathbf{T}_{4} \\
\mathbf{0 \%}\end{array}$ & $\begin{array}{l}\mathbf{T}_{5} \\
\mathbf{1 5 \%}\end{array}$ & $\begin{array}{l}\mathbf{T}_{6} \\
\mathbf{3 0 \%}\end{array}$ & $\begin{array}{l}\mathbf{T}_{7} \\
\mathbf{0 \%}\end{array}$ & $\begin{array}{l}\mathbf{T}_{8} \\
15 \%\end{array}$ & \\
\hline Maize & 30 & 20 & 10 & 30 & 20 & 10 & 30 & 20 & 10 \\
\hline Wheat offal & 20 & 20 & 20 & 20 & 20 & 20 & 20 & 20 & 20 \\
\hline Rice husk & 25 & 20 & 20 & 25 & 20 & 20 & 25 & 20 & 20 \\
\hline Soy bean & 20 & 20 & 20 & 20 & 20 & 20 & 20 & 20 & 20 \\
\hline M. oleifera & - & 15 & 30 & - & - & - & - & - & - \\
\hline A. indica & - & - & - & - & 15 & 30 & - & - & - \\
\hline A. Africana & - & - & - & - & - & - & - & 15 & 30 \\
\hline Fish meal & 1.00 & 1.00 & 1.00 & 1.00 & 1.00 & 1.00 & 1.00 & 1.00 & 1.00 \\
\hline Bone meal & 1.50 & 1.50 & 1.50 & 1.50 & 1.50 & 1.50 & 1.50 & 1.50 & 1.50 \\
\hline Oyster shell & 1.50 & 1.50 & 1.50 & 1.50 & 1.50 & 1.50 & 1.50 & 1.50 & 1.50 \\
\hline Premix & 0.50 & 0.50 & 0.50 & 0.50 & 0.50 & 0.50 & 0.50 & 0.50 & 0.50 \\
\hline Salt & 0.50 & 0.50 & 0.50 & 0.50 & 0.50 & 0.50 & 0.50 & 0.50 & 0.50 \\
\hline Total & 100 & 100 & 100 & 100 & 100 & 100 & 100 & 100 & 100 \\
\hline
\end{tabular}

\section{Data analysis}

All data collected were subjected to a $3 \times 3$ completely randomized design using SPSS (Release 20.0) statistical package (SPSS, 2011). Model sums of squares were partitioned to linear, quadratic and cubic trends (Gomez and Gomez, 1983) and significant differences were compared using Duncan's multiple range test (Duncan, 1955). 


\section{Bolarin, Oni, Olanite, Onwuka}

Results

The performance characteristics of grower rabbits (Table 2) revealed that the parameters were significantly $(\mathrm{P}<0.05)$ affected with the exception of average initial weight which ranged from $516.42 \mathrm{~g}$ to $516.67 \mathrm{~g}$. It was observed that rabbits fed $30 \%$ inclusion level of $M$. oleifera leaf meal had highest average final live weight $1475.87 \mathrm{~g}$, followed closely by $15 \% \mathrm{M}$. oleifera leaf meal (1445.00 g) but were higher than $15 \%$ and $30 \%$ A. indica leaf meal and A. africana leaf meal.

Average daily feed intake ranged from 52.74 to 60.40 g. Rabbits fed diet containing $0 \% \mathrm{M}$. oleifera; $A$. africana leaf meal and $A$. indica leaf meal were significantly $(\mathrm{P}<0.05)$ higher on average daily feed intake value of $59.60 \mathrm{~g}, 60.34 \mathrm{~g}$ and $60.40 \mathrm{~g}$ respectively. Rabbits on $15 \% \mathrm{~A}$. africana leaf meal had the least $(\mathrm{P}<0.05)$. Best feed conversion ratio of $4.92 \mathrm{~g}$ was recorded in $15 \% M$. oleifera leaf meal followed by $30 \%$ Moring a oleifera leaf meal $4.94 \mathrm{~g}$ and $15 \%$ A. africana leaf meal $4.95 \mathrm{~g}$. Similar values were obtained for all treatments with the exception of the control diet $0 \%$ and $30 \% \mathrm{~A}$. indica leaf meal which had the worst $(\mathrm{Q}: \mathrm{C}: \mathrm{P}<0.05)$ feed conversion ratio. The average daily weight gain as affected by inclusion of leaf meals followed a significant cubic trend $(\mathrm{C}$ : $\mathrm{P}<0.05$ ) which ranged from 9.33 to $11.42 \mathrm{~g}$. Rabbits fed $30 \%$ M. oleifera leaf meal gained $11.42 \mathrm{~g}$ which was significantly $(\mathrm{P}<0.05)$ higher than other treatments while rabbits fed with $0 \%$ M. oleifera leaf meal had the least $(\mathrm{P}<0.05)$ value of $9.33 \mathrm{~g}$.

Table 2: Effect of the dietary leaf meals on the performance characteristics of grower rabbits

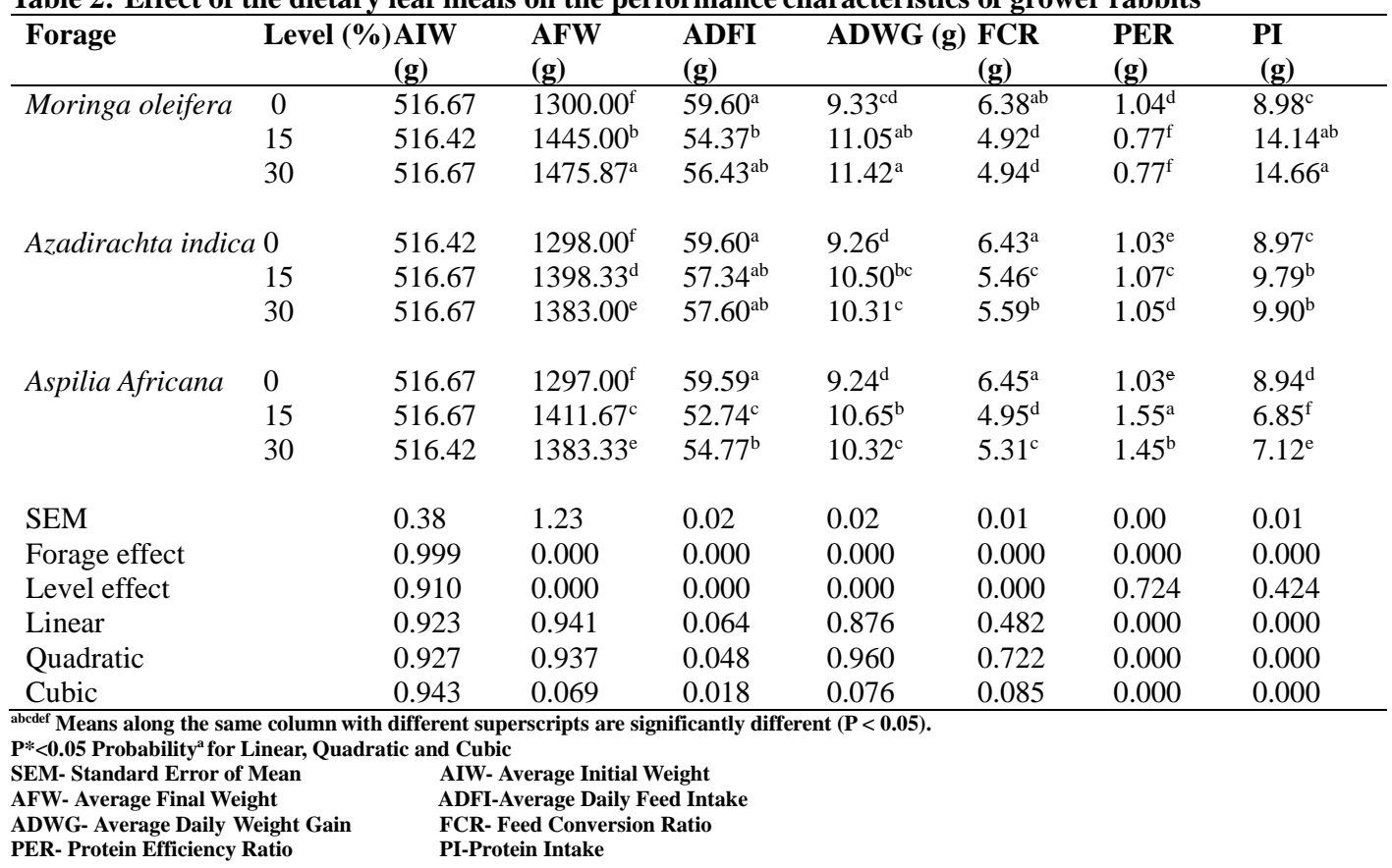

The nitrogen utilization was significant across the treatments except for faecal nitrogen ranged from $1.85 \%$ to $2.32 \%$ and nitrogen output ranged from $2.71 \%$ to
$3.15 \%$ in Table 3. Nitrogen intake increased significantly $(\mathrm{C}: \mathrm{P}<0.05)$ from $0 \%$ to $30 \%$ across the treatments. Highest value of $14.88 \%$ was achieved at $20 \%$ M. oleifera 
leaf meal.

Urinary nitrogen followed similar trend with a higher value of $1.23 \%$ achieved at $30 \%$ A. indica leaf meal resulting in a significant linear, quadratic and cubic relationships (L: Q: C: P<0.05). Nitrogen absorbed and nitrogen retention followed similar trend significantly as the inclusion levels increased with increasing levels across the dietary treatments $(\mathrm{C}: \mathrm{P}<0.05)$. $30 \% M$. oleifera leaf meal recorded a significant $(\mathrm{P}<0.05)$ higher value of $12.94 \%$ for nitrogen absorbed and $12.02 \%$ for nitrogen retention as the control diet had the least value. \% nitrogen retention ranged from $73.88 \%$ to $80.76 \%$ was significant $(\mathrm{P}<0.05)$ across the dietary treatments.

The results presented in Table 4 shows that the highest $\mathrm{Hb}$ and $\mathrm{RBC}$ values of 13.10 $\mathrm{g} / \mathrm{dl}, 13.07 \mathrm{~g} / \mathrm{dl}$ and $\left.7.01,7.03 \times 10^{6} / \mu \mathrm{l}\right)$ were obtained in $15 \%$ and $30 \%$ M. oleifera inclusion levels which were significantly $(\mathrm{P}<0.05)$ influenced. The RBC counts was significantly affected in a linear, quadratic and cubic trends (L: Q: C: $\mathrm{P}<0.05$ ). WBC counts ranged from $3.37 \times 10^{3} / \mu 1$ to 8.40 $\mathrm{x} 10^{3} / \mu \mathrm{l}$ where $15 \%\left(8.30 \times 10^{3} / \mu \mathrm{l}\right)$ and $20 \%$ $\left(8.40 \times 10^{3} / \mu 1\right) A$. indica leaf meal had highest value which was significantly (L: $\mathrm{Q}: \quad \mathrm{C}: \quad \mathrm{P}<0.05)$ different from other treatments. Inclusion level of $M$. oleifera leaf meal at $15 \%$ had the least value of (3.37 $\mathrm{x} 10^{3} / \mu 1$ ) with no differences when comparing $0 \%\left(4.17 \times 10^{3} / \mu \mathrm{l}\right)$ and $30 \%$ $\left(3.60 \times 10^{3} / \mu 1\right)$ M. oleifera leaf meal and $0 \%$ A. africana leaf meal $4.00 \times 10^{3} / \mu 1$ respectively.

There was a slight increase in the values of Total serum protein $(\mathrm{g} / \mathrm{dl})$ and Albumin $(\mathrm{g} / \mathrm{dl})$ which ranged from 5.60 to $7.40(\mathrm{~g} / \mathrm{dl})$ and 3.77 to $4.20(\mathrm{~g} / \mathrm{dl})$ respectively and were significant $(\mathrm{L}: \mathrm{Q}: \mathrm{P}<0.05)$.

Globulin value ranged from 1.57 to 3.40 (g/dl). The inclusion levels of M. oleifera leaf meal and A. africana leaf meal declined significantly as the inclusion levels increases from $0 \%$ to $30 \%$ across the treatments. The creatinine value ranged from 0.26 to 1.37 (mg/dl) but had no significant $(\mathrm{P}>0.05)$ differences across the treatment.

Table 5 shows the inclusion levels of the experimental diets on carcass parameters of grower rabbits. There were significant $(\mathrm{P}<$ 0.05) differences for all the cut part parameters with the exception of the head and neck weight that were not $(\mathrm{P}>0.05)$ influenced by the dietary treatments. The results obtained for the average final live weight shows that rabbits fed $30 \% M$. oleifera leaf meal obtained highest value $1475.87 \mathrm{~g}$ followed by $15 \%$ M. oleifera leaf meal $1445.00 \mathrm{~g}$ which was better than $(\mathrm{P}<$ $0.05) 1411.67 \mathrm{~g}$ obtained for rabbits in $15 \%$ inclusion level of $A$. africana leaf meal and $15 \%$ A. indica leaf meal 1398.33 g. The values obtained for fore limb increased with increasing levels of $M$. oleifera leaf meal and decrease with increasing levels in $A$. africana leaf meal from $0 \%$ to $30 \%$. For the inclusion levels of $A$. indica, the values increased from $0 \%$ to $15 \%$ and declined further as the levels of inclusion increased to $30 \%$ in the diet. The values ranged from 111.39 to $126.39 \mathrm{~g}$. Hind limb ranged from 143.26 to $174.23 \mathrm{~g}$ the values increased with increasing levels for $M$. oleifera leaf meal while the inclusion levels of $A$. africana leaf meal and $A$. indica leaf meal increased with increasing level from $0 \%$ to $15 \%$ that later declined as the levels increased to $30 \%$ in the diet. However, loin weight was significant $(\mathrm{P}<0.05)$ across the treatments at quadratic and cubic trends (Q: $\mathrm{C}: \mathrm{P}<0.05)$. Values ranged from (148.39 $\mathrm{g}$ to $194.20 \mathrm{~g}) \mathrm{M}$. oleifera leaf meal, (121.74 g to $177.53 \mathrm{~g})$ and A. indica leaf meal (170.07 g to $187.51 \mathrm{~g}) A$. africana leaf meal and respectively. $M$. oleifera leaf meal at $30 \%$ had the highest of $194.20 \mathrm{~g}$ and the least value was obtained at 
Bolarin, Oni, Olanite, Onwuka

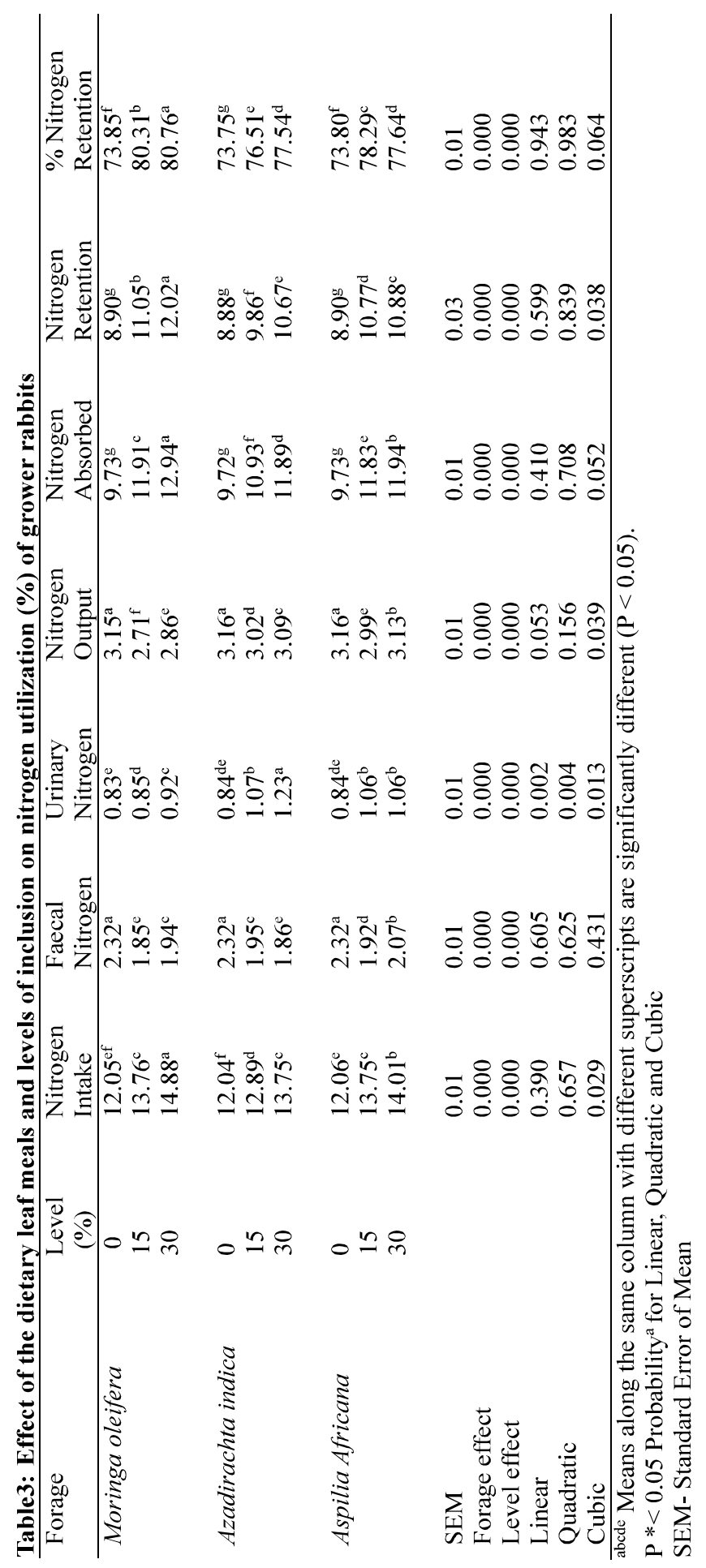

143 
Rabbits fed diet containing Moringa oleifera, Aspilia africana and Azadirachta indica leaf meals

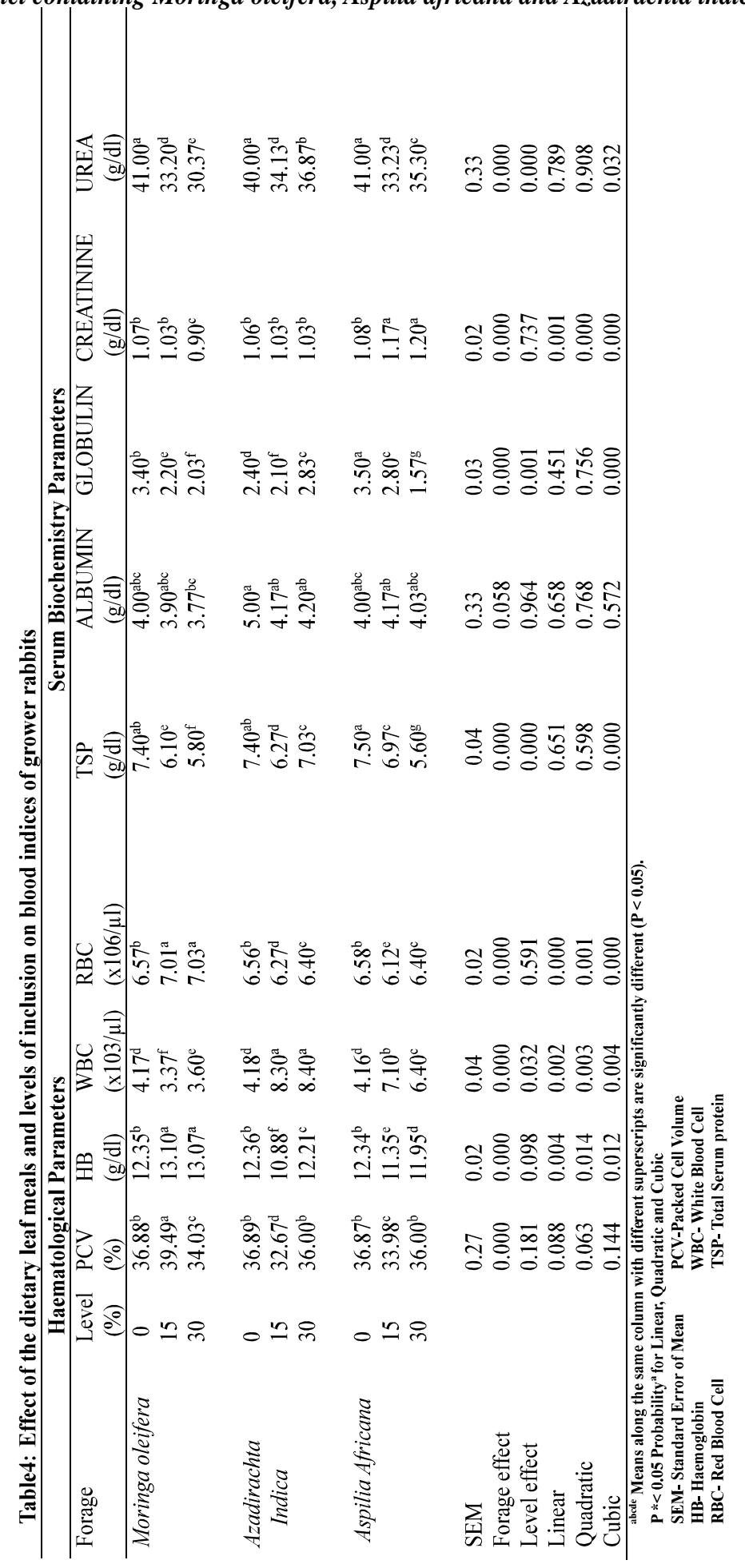

144 
Bolarin, Oni, Olanite, Onwuka

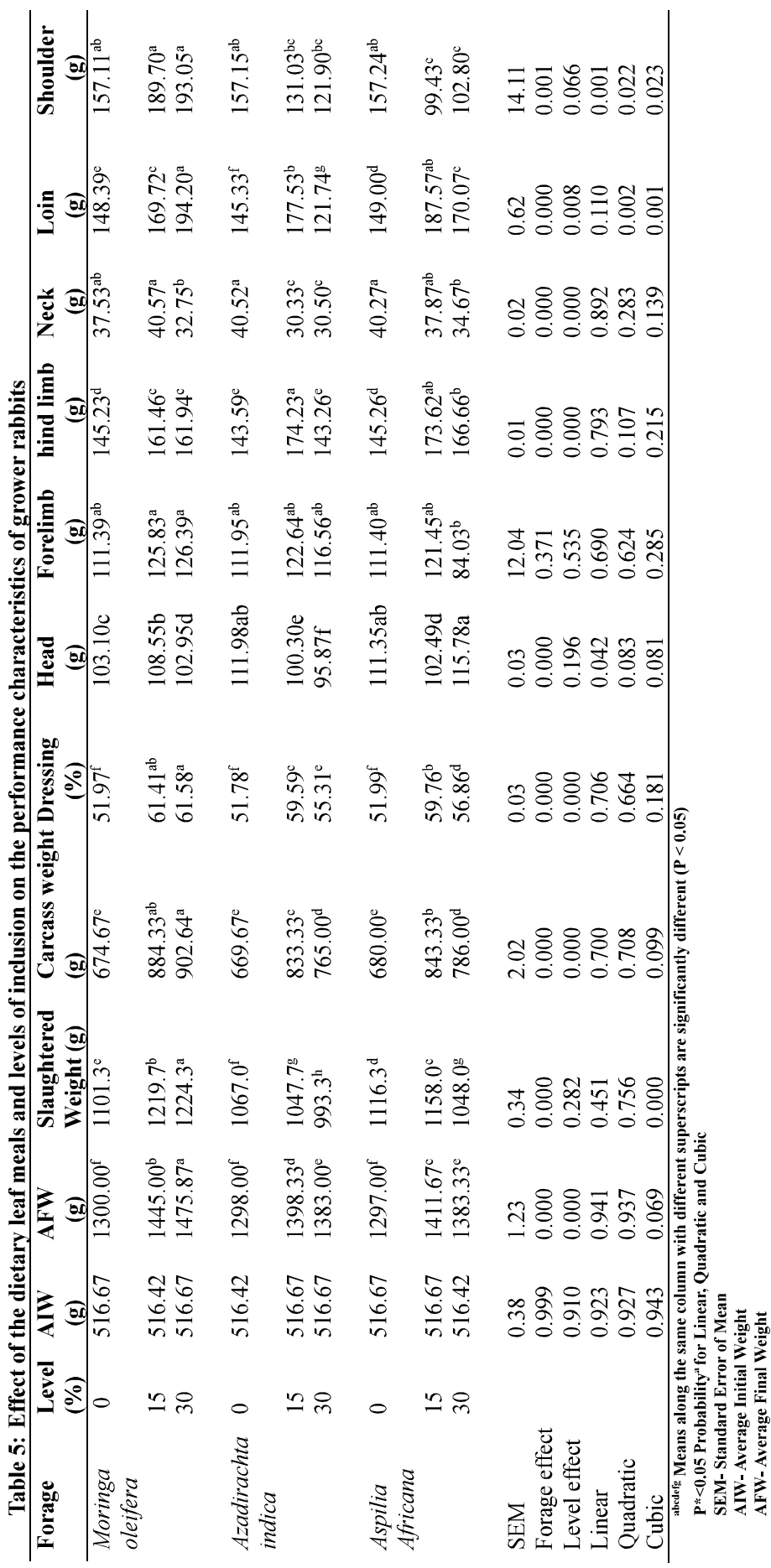


$30 \%$ A. indica leaf meal $121.74 \mathrm{~g}$. Rabbits fed $15 \%$ and $30 \%$ inclusion levels of $M$. oleifera leaf meal $189.70 \mathrm{~g}$ and $193.05 \mathrm{~g}$ respectively had highest $(\mathrm{L}: \mathrm{Q}: \mathrm{C}: \mathrm{P}<0.05)$ value for shoulder weight while the inclusion level of $A$. indica leaf meal at $30 \%$ obtained the least $(\mathrm{L}: \mathrm{Q}: \mathrm{C}: \mathrm{P}<0.05)$ value $121.90 \mathrm{~g}$.

\section{Discussion}

The performance characteristics of rabbits fed the dietary treatments as influenced by the levels of inclusion of the leaf meals shown in Table 2 revealed that the parameters measured were significantly $(\mathrm{P}<0.05)$ affected. The animals had similar body weight at the start of the experiment. Rabbits fed 30\%MOM had the higher final weight than their counterparts fed control and $30 \%$ AAM and AIM diets.

The increased weight gain observed in treatment 3 with rabbits fed $30 \% \mathrm{MOM}$ could be atrributed to the high crude protein content of the leaf compared to the control diet and other treatment groups. The increase in fibre level resulted to a decrease in body weight gain.

However, the reduced weight gain of rabbits fed A. africana and A. indica leaf meals agreed with the findings of Olabode et al. (2013). Ogbuewu et al. (2010) also reported a reduction in growth rate of rabbits fed neem leaves. Poor weight gain observed in 30\% AAM and AIM compared to $30 \% \mathrm{MOM}$ could be due to the presence of secondary metabolite observed in the leaves. The feed conversion ratio decreased with a decrease in daily feed intake. Poor FCR obtained could be a reflection of the poor feed quality and ultilization of the diet. The findings of Esonu et al. (2006); Ogbuewu et al.(2010); Obikaonu et al. (2012) revealed that $15 \%$ AIM is the tolerance level for laying birds and adult rabbits. The values were similar to the findings of Sese et al. (2013) with value of 4.39- 6.44g when weaner rabbits were fed Mucuna utilis leaf meal but were generally, higher than the report of 2.24$2.53 \mathrm{~g}$ by Olabode et al. (2013).

High nitrogen intake and nitrogen retention obtained in this study at 30\% MOM could be attributed to high digestibility of the nutrients in the dietary treatments. Mc Donald et al. (1993) reported that the dietary nitrogen intake by animals is related to the proportion of nitrogen in the feed. Nitrogen could not be stored within the body system of animals; excessive intake of nitrogen above optimum requirement will result in wastage as accumulation of gas in the rumen result in belching or eructation. The values for faecal and urinary nitrogen in this study $1.85-2.32 \%$ and $0.82-1.23 \%$ were generally higher than $0.41-0.64 \%$ and $0.14-$ $0.39 \%$ reported by Asaolu et al. (2011).

Aro et al. (2013) stated that haematological components, which consists of red blood cells, white blood cells or leucocytes, mean corpuscular haemoglobin and mean corpuscular haemoglobin concentration are valuable in monitoring feed toxicity, especially, with feed constituents that affect the blood as well as the health status of livestock and even humans. The PCV values (\%) for the treatment groups were below normal range for healthy growing rabbits (32.67-39.49) though significant differences $(\mathrm{P}<0.05)$ existed among treatment groups. Values obtained shows that the feed were nutritionally adequate for the growing rabbits. Reduction in the concentration of PCV in the blood usually suggests the presence of a toxic factor (e.g. Haemaglutinin) which has adverse effect on blood formation (Oyawoye and Ogunkunle, 1998). Lower PCV and $\mathrm{Hb}$ value obtained at $15 \%$ AIM is as a result of genetic differences in the animals. $15 \%$ and $30 \%$ AIM had the highest WBC. High white 


\section{Bolarin, Oni, Olanite, Onwuka}

blood cell count is usually associated with microbial infection or the presence of foreign bodies or antigens in the circulating system (Ahamefule et al., 2008). Similarities also exist between the red blood cell counts. Increase in Red blood cell counts were associated with high quality protein and disease free animal.

Furthermore, Total protein $(\mathrm{g} / \mathrm{dl})$ has been reported as an indication of the protein retained in the animal body (Akintola and Abiola, 1999; Esonu et al., 2001). The values fell within the range (5.4-7.5) for rabbits. The presence of increased blood urea in this study shows that the animal might be in a state of negative nitrogen balance. This could be attributed to the presence of some bioactive compounds contained in the diet. Eggum (1970) reported that blood urea levels are associated with poor protein quality or excess tissue associated with protein deficiency (Oduye and Adaderoh, 1976). The presence of increasing urea and creatinine concentration in the blood is used in the evaluation of the effects of chemicals on the kidney (Davis and Berndt, 1994).

The slaughtered weight values of 993.3$1224 \mathrm{~g}$ in this study were generally lower than the $1290.33-1530.33 \mathrm{~g} ; 1200-1425 \mathrm{~g}$; 1809-2281g reported by (Nuhu, 2010; Bolarin et al., 2013 ; EL-Badawi et al., 2014) respectively but were similar to the report of 988.24-1335.00 $\mathrm{g}$ by Biya et al.(2008) and higher than 849.00-877.00 g by Ogbuewu et al. (2010). The lower slaughtered weight observed in this study is probably because of lower feed intake by the rabbits. The inclusion level of $M$. oleifera leaf meal (MOM) at $30 \%$ in this study had highest slaughtered weight value and was superior to the control diet and $30 \%$ AAM and AIM. Higher slaughtered weight of rabbits fed control diet over those on $15 \%$ and $30 \%$ inclusion of AIM showed the superiority of the diet over $15 \%$ and $30 \%$ inclusion levels. The dressing percentage values obtained from the present study were higher than 46.51-52.27 g reported by Biya et al. (2008) but lower than those reported by Bolarin et al. (2013) and 62.96-65.55 g observed by EL- Badawi et al. (2014). However, the values were similar to the observations of $51.59-53.50 \%$ reported by Ogbuewu et al. (2010).

It was observed that there were variations in the retail part across the dietary treatments. Lebas (1991) however, reported that variation in nutritional plane of growing rabbits might modify the anatomical equilibrium and chemical composition of carcass tissue. Fanimo et al. (2003) also reported that forelimb, hind limb, and loin are the most economically important portion of carcass because they provide the greatest portion of edible meat.

\section{Conclusion and Recommendations}

From this study it was observed that for optimum performance of rabbit, $15 \%$ and $30 \%$ inclusion level of $M$. oleifera should be fed for good performance of the rabbits. This study also confirms the safety of Aspilia africana leaf meal and Neem leaf meal in feeding rabbit. It could be tolerated at $15 \%$ inclusion level for rabbit to obtain the highest value of live body weight, enhancing feed intake, and improved feed conversion ratio without any detrimental effects on blood parameters.

\section{References}

Ahamefule, F. O., Obua, B. E., Ukweni, I. A., Oguike, M. A. and Amaka, R. A. 2008. Haematological and biochemical profile of weaner rabbits fed raw or processed pigeon pea seed meal based diets. African Journal of Agricultural Research, 
Rabbits fed diet containing Moringa oleifera, Aspilia africana and Azadirachta indica leaf meals

3(4):315-319.

Akinmutimi, A. H. 2004. Evaluation of sword bean (Canavalia gladiata) as an alternative Feed resource for broiler chickens. Ph.D. Thesis, Department of Non-ruminant Animal Production, Michael Okpara University of Agriculture, Umudike, Nigeria.

Akintola, S. O. and Abiola, S. S. 1999. Blood Chemistry and carcass yield of cockerels fed melon husk diets. Tropical Journal of Animal Science 2: 39-39.

Aro, S. O., Ogunwale, F. F. and Falade, O. A. 2013. Blood viscosity of finisher cockerel fed dietary inclusions of fermented cassava tuber wastes. Proceedings of the 18th Annual Conf. of Anim. Sci. Assoc. of Nig., 74-77.

Asaolu, V. O., Binuomote, R. T., Akinlade, J. A., Oyelami, O. S. and Kolapo, K. O. 2011. Utilization of Moringa oleifera Fodder Combinations with Leucaena leucocephala and Gliricidia sepium Fodders by West African Dwarf Goats. International Journal of Agricultural Research 6 (8):607619.

Atansuyi, A. J., Akinyemi, M. B., OmoAkeju, M. O., Chineke, C.A. and Aleteor, V. A. 2012. Haematology indices of rabbit fed graded levels of two fibre sources. Proceedings of the $10^{\text {th }}$ World Rabbit Congress, September, 3-6, 2012. Sham Elsheikh, Egypt, Pp. 713-717.

Davis, M. E. and Berndt, W. D. 1994. Renal methods for toxicology. In: Hayes, A.W. (eds). Principles and methods of toxicology, 3rd Ed. New York Raven; 871 - 894.
Duncan, D. B 1955. Multiple Range and Multiple F-tests. Biomedical. 11: 142.

Eggum, B. O., 1970. Blood urea measurement as a technique for assessing protein quality. British Journal of Nutrition, 24: 983-988.

Esonu, B. O., Emenelom, O. O., Udedibie, A. B. I., Herbert, U., Ekpor, C. F., Okoli, I. C. and Iheukwumere, F. C. 2001. Performance and blood chemistry of weaner pigs fed raw Mucuna (Velvet bean) meal. Trop. Anim. Prod. Invest, 4:49-54.

Esonu, B. O., Opara, M. N., Okoli, I. C., Obikaonu, H. O., Udedibie C. and Iheshiulor, O. O. M. 2006. Physiological responses of laying birds to Neem (Azadirachta indica) leaf meal based diets, body weight, organ characteristics and haematology. Online Journal Health and Allied Science.2: 4 http//www.ojhas.org/issue 18/2006-2-4.htm.

Ewuola, E. O., Jimoh, O. A., Atuma, O. V. and Sodipe, O. D. 2012. Haematological and serum biochemical response of growing rabbits fed graded levels of Moringa oleifera leaf meal. Proceedings of the $10^{\text {th }}$ World Rabbit congress, September 3-6, 2012.Sharm- EI-Sheikh-, Egypt, Pp.679-683.

Fanimo, A. O., Oduguwa, O. O., Alade, A. A., Ogunaike, T. O. and Adeshinwa, A. K. 2003. Growth performance, nutrient digestibility and carcass characteristics of growing rabbits fed cashew apple waste. Livestock Research for Rural Development, 15(8).

FAOSTAT, 2011. www. fao.org /es/ess/faostat/food/security/index/ en.htm 
Gomez, A. K. and Gomez, A. A. 1983. Statistical procedures for Agricultural Research, second edition. International rice research institute, the Philippines.

Lebas, F. 1991. Alimentation pratique des lapins en engrassement. Cunniculture, 18:273-275.

Mc Donald, P., Edwards R. A. and Green Halgh, J. F. D. 1993. In: Animal nutrition $4^{\text {th }}$ edition. Longman Scientific and Technical, John Wiley and sons Inc. New York.

Obikaonu, H. O., Okoli, I. C., Opara, M. N., Okoro, V. M. O., Ogbuewu, I. P., Etuk, E. B. and Udedibie, A. B. I. 2012. Haematological and serum biochemical indices of starter broilers fed neem (Azadirachta indica) leaf meal. Online Journal of Animal and Feed Research Volume 1, Issue 4: 150-154 (2011).ISSN 2228-7701.

Oduye, O. O. and Adaderoh, B. K. 1976. Biochemical values of apparently normal Nigerian sheep. Nigerian veterinary Journal, 5(1):43-50.

Ogbuewu, I. P., Uchegbu, M. C., Okoli, I. C., Iloeje, M. U .2010. Assessment of blood chemistry, weight gain and linear body measurements of pre-puberal buck rabbits fed different levels of Neem (Azadirachta indica A. Juss.) leaf meals. Chilean Journal of Agricultural Research. 70(3):515-520.
Olabode, A. D., Onyimonyi, A. E., Ezekwe, A. G. and Okelola, O. E. 2013. Performance Characteristics and Economic Evaluation of Laying Birds Fed Graded Levels of Neem Leaf Meal. International Journal of Agriculture and Biosciences P-ISSN: 2305-6622 EISSN: 2306-3599.

Oyawoye, E. O. and Ogunkunle, M. 1998. Physiological and biochemical effects of raw jack beans on broilers. Proceedings of annual Conference of Nigerian Society of Animal Production, 23: 141-142.

Roberts, K. M., Murray, D., Daryl, K., Grammer, K. and Rodwell, W. 2003. Harper Biochemistry $29^{\text {th }}$ edition.

Sese, B. T., Okpeku, M. and Patani, I. 2013. Tropical Velvet Bean (Mucuna Utilis) Leaf Meal as Unconventional Protein Supplement in the Diet of Broiler Chicks. Journal of Animal Science Advances 2013, 3(11): 575-583.

SPSS/PC+. 2011. Users guide. Mc GrawHill, NY.

Received: $10^{\text {th }}$ July, 2017

Accepted: $9^{\text {th }}$ December, 2017 